\title{
Enterotoxin production by Staphylococcus aureus clones and detection of Brazilian epidemic MRSA clone (III::B:A) among isolates from food handlers
}

\author{
M. J. S. SOARES, N. H. TOKUMARU-MIYAZAKI, A. L. S. NOLETO and A. M. S. FIGUEIREDO \\ Universidade Federal do Rio de Janeiro, Instituto de Microbiologia Prof. Paulo de Góes, Departamento de \\ Microbiologia Médica, Laboratório de Biologia Molecular de Bactérias, CCS-BI l, Cidade Universitária, llha do \\ Fundão, Rio de Janeiro, 21941.590 and * Universidade Federal do Piauí, Departamento de Parasitologia e \\ Microbiologia, Campus Ministro Petrônio Portela, SG 16, 64049.550, Brazil
}

\begin{abstract}
Staphylococcus aureus is a major bacterial pathogen involved in a wide range of diseases varying from infections to toxaemia. Staphylococcal food-poisoning syndrome is caused by ingestion of bacterial enterotoxins. These toxins are microbial superantigens and may also be virulence factors involved in staphylococcal infection. This study determined the enterotoxin types and pulsed-field gel patterns found among $S$. aureus isolates obtained from food handlers in community or hospital-located kitchens. Staphylococcal enterotoxin $C$ was the most frequent enterotoxin produced. The data also suggested horizontal spread of ent genes among isolates belonging to the Brazilian epidemic MRSA clone III::B:A. A subclone of MRSA clone III::B:A was isolated from two hospital kitchen workers. This was the first report of this clone from a hospital in Teresina, Piauí State, although the presence of this MRSA clone has already been reported in six other Brazilian cities.
\end{abstract}

\section{Introduction}

The importance of Staphylococcus aureus in diseases ranging from acute infections-which may be either localised or invasive - to acute toxaemia is well-known [1-3]. Staphylococcal food-poisoning syndrome is an intoxication caused by ingestion of staphylococcal enterotoxins (SEs). These toxins are characterised on the basis of their immunological reactivity and have been designated as SEA, SEB, SEC1, SEC2, SEC3, SED, SEE and SEH [4-11]. SEs are mitogenic for lymphocytes and are called microbial superantigens because of their ability to stimulate subsets of $\mathrm{T}$ cells by binding to MHC class II molecules (Ia) on the antigen-presenting cells $[12,13]$.

Genetic analysis has shown that the SEA gene (entA) is inserted within bacteriophage DNA that is present in at least two integration sites on the staphylococcal chromosome [14]. The SEB gene (entB) is associated with a large genetic element on the staphylococcal chromosome, but it is not known whether this is an integrated plasmid, phage or transposon [15]. The SEC

Received 2 July 1996; revised version accepted 21 Aug. 1996.

Corresponding author: Dr A. M. S. Figueiredo. gene (ent C) is also chromosomally located [16], but the SED gene (entD) is located on a plasmid that also carries penicillin and cadmium resistance genes [17]. Finally, the SEE gene (entE) is associated with a defective phage inserted in the chromosome [18]. Despite this detailed genetic characterisation, little is known of the evolution and spread of ent genes among S. aureus strains. However, Renaud et al. [19] studied 39 SEB strains and showed that these isolates derived from only three clones.

Acquisition of antibiotic resistance by $S$. aureus has been recognised as a major health problem. Numerous hospital infections, worldwide, are caused by methicillin-resistant $S$. aureus (MRSA) [20,21] and a foodinitiated hospital outbreak caused by MRSA has been described [22]. This paper investigated enterotoxin production by different $S$. aureus clones-including the Brazilian epidemic MRSA clone III::B:A [23] isolated from food handlers in community and hospital-located kitchens.

\section{Materials and methods}

Study population

In total, 196 food handlers from four hospital kitchens and five community-located restaurants in Teresina 
City, Piaui State, in the northeast of Brazil, were screened. There was no indication of staphylococcal infection in any of the food handlers and none had used antibiotics in the preceding 3 months.

\section{Bacterial strains}

Swabs from anterior nares were streaked on Trypticase Soy Agar (TSA; Difco) supplemented with sheep blood (Difco) $5 \% \mathrm{v} / \mathrm{v}$. The plates were incubated at $37^{\circ} \mathrm{C}$ for $24 \mathrm{~h}$. Fingernail specimens were streaked on Mannitol Salt Agar (MSA; Difco) and incubated at $37^{\circ} \mathrm{C}$ for 72 h. Five typical Staphylococcus colonies from both plates were selected. Identification as $S$. aureus was by routine tests [24]. Stock cultures were prepared in sterile glycerol $10 \% \mathrm{v} / \mathrm{v}$ and stored at $-70^{\circ} \mathrm{C}$. In addition, six multiresistant $S$. aureus hospital isolates belonging to the Brazilian epidemic clone III::B:A [23] were used for enterotoxin production and detection studies.

\section{Enterotoxin production and detection}

The cellophane-over-agar method described by Hallander [25], modified by Jarvis and Lawrence [26], was used for enterotoxin production. The optimum-sensitivity plate (OSP) method was used for enterotoxin detection [27]. Purified enterotoxins and specific antisera used in the immunodiffusion test were kindly provided by Dr M. S. Bergdoll (Food Research Institute, University of Wisconsin).

\section{DNA preparation}

All procedures for preparation of genomic or plasmid DNA were as described previously [28], except that $S$. aureus cell lysis was achieved following pre-incubation of the bacteria with $90 \mathrm{U}$ of lysostaphin (Sigma) for $3 \mathrm{~h}$ at $37^{\circ} \mathrm{C}$.

\section{Pulsed-field gel electrophoresis}

Preparation of bacterial DNA and digestion with Sma I were as described previously [29]. Pulsed-field gel electrophoresis (PFGE) was performed with a CHEFDR III apparatus (BioRad) and a voltage of $6 \mathrm{~V} / \mathrm{cm}$, ramped with an initial forward time of $1 \mathrm{~s}$ and a final forward time of $30 \mathrm{~s}$. Agarose $1 \% \mathrm{w} / \mathrm{v}$ gels were run for $23 \mathrm{~h}$ at $11.3^{\circ} \mathrm{C}$ in $50 \mathrm{~mm}$ Tris buffer containing $50 \mathrm{~mm}$ boric acid and $0.2 \mathrm{~mm}$ EDTA, pH 8.0 $(0.5 \times \mathrm{TBE})$. Gel staining and photography were as described previously [28]. Strains that shared the same PFGE pattern were assigned a common capital letter. Strains that differed in one-to-three bands were assigned a common capital letter and a subtype number. Strains with more than three band differences were assigned a different capital letter and considered to be another clone $[30,31]$.

\section{Antibiotic susceptibility}

The Kirby-Bauer test was performed as recommended by the National Committee for Clinical Laboratory Standards [32]. The disks (Cecon Ltd., Brazil) used contained the following antibiotics: penicillin G (PN, $10 \mathrm{U}$ ); oxacillin (OX, $1 \mu \mathrm{g}$ ); ampicillin (AP, $10 \mu \mathrm{g}$ ); gentamicin (GN, $10 \mu \mathrm{g}$ ); amikacin (AM, $30 \mu \mathrm{g}$ ); tetracycline (TC, $30 \mu \mathrm{g})$; cephalothin (CF, $30 \mu \mathrm{g})$; erythromycin (EI, $15 \mu \mathrm{g}$ ); clindamycin (CL, $2 \mu \mathrm{g}$ ); imipenem (IM, $10 \mu \mathrm{g}$ ); trimethoprim-sulphamethoxazole (SFT, $25 \mu \mathrm{g}$ ); and vancomycin (VC, $30 \mu \mathrm{g}$ ).

\section{Screening test for methicillin resistance}

This test was performed as described previously [33], except that methicillin $25 \mathrm{mg} / \mathrm{L}$ agar plates were prepared with Mueller-Hinton Agar (MHA, Difco) instead of TSA. After an incubation period of $24 \mathrm{~h}$ at $37^{\circ} \mathrm{C}$, any growth was taken as an indication of resistance and examined further with a $m e c A$-specific DNA probe (see below).

\section{Preparation of the mecA DNA probe}

The fluorescein-labelled mecA DNA probe used in this study was the 1.196-kb Pst I-Xba I fragment (MF13) from the mecA gene of the Australian type strain ANS46, cloned in pTZ219 [34]. The probe was recovered following electrophoresis of restriction endonuclease-digested plasmid DNA on an agarose $0.8 \%$ w/v gel with a Sephaglas Bandprep Kit (Pharmacia) and labelled with fluorescein by the ECL Random Prime Labelling System (Amersham International) as recommended by the manufacturer.

\section{Dot-blot hybridisation}

Samples $(3 \mu \mathrm{l})$ of genomic DNA preparations were blotted on to PhotoGene Nylon Membranes (Gibco BRL) after denaturation of the DNA at $100^{\circ} \mathrm{C}$ for $5 \mathrm{~min}$. The DNA was fixed by baking at $80^{\circ} \mathrm{C}$ for $2 \mathrm{~h}$. Hybridisation and wash conditions were according to the ECL protocol. Positive hybridisation results were detected following incubation with anti-fluoresceinHRP conjugate as recommended for the ECL system. The signals generated were recorded on X-ray film (X OMAT XK 1; Kodak). $S$ aureus strain Col was used as a positive control for $m e c A$ and was obtained from Dr A. Tomasz, Rockefeller University, New York.

\section{Results}

\section{S. aureus colonisation}

S. aureus was isolated from $91(46.4 \%)$ of the 196 food handlers studied. Among the 91 carriers, isolation of $S$. aureus from the nares was more common than isolation from hands (Table 1). It was also observed that the frequency of nasal $S$. aureus carriage was higher amongst hospital workers than in workers from 
Table 1. Carriage of $S$. aureus by 196 food handlers working in community- or hospital-located kitchens

\begin{tabular}{|c|c|c|c|c|}
\hline \multirow{2}{*}{$\begin{array}{l}\text { Kitchen } \\
\text { type }\end{array}$} & \multirow{2}{*}{$\begin{array}{c}\text { Number of } S \text {. aureus } \\
\text { carriers/number of } \\
\text { workers examined }(\%)\end{array}$} & \multicolumn{3}{|c|}{$\begin{array}{l}\text { Number of colonisation sites } \\
\text { (percentage of } S \text {. aureus carriers) }\end{array}$} \\
\hline & & Nares & Hands & Nares and hands \\
\hline Community & $42 / 97 \quad$ (43.3) & $21(50.0)$ & $11(26.2)$ & $10(23.8)$ \\
\hline Hospital & $49 / 99 \quad(49.5)$ & $39(79.6)$ & $4 \quad(8.2)$ & $6(12.2)$ \\
\hline Total & $91 / 196(46.4)$ & $60(65.9)$ & $15(16.5)$ & $16(17.6)$ \\
\hline
\end{tabular}

community-located kitchens. In contrast, hand colonisation with $S$. aureus was commoner among food handlers from community-located kitchens than among hospital kitchen workers (Table 1).

\section{Enterotoxin production}

Of 91 carriers, $26(28.6 \%)$ were colonised by enterotoxin-producing strains. Sixteen $(61.5 \%)$ of these 26 workers harboured enterotoxigenic strains of $S$. aureus in their nose only, seven $(27 \%)$ on their hands only, and three $(11.5 \%)$ at both sites. The strains produced SEA, SEB, SEC, SED or SEE, or combinations of these toxins. The percentage of carriers from whom enterotoxin-producing strains were isolated was $32.6 \%$ for hospital workers and $23.8 \%$ for food handlers from community-located kitchens. Overall, SEC was the toxin produced most frequently (Table 2). Isolates that produced one enterotoxin type alone were most common; however, seven $(26.9 \%)$ of the 26 carriers yielded strains that produced a combination of different enterotoxin types (Table 2).

\section{Antibiotic susceptibility and detection of the mecA gene}

The susceptibility profiles of $130 \mathrm{~S}$. aureus isolates from the food handlers were analysed (Table 3 ). Although $81 \%$ and $94 \%$ of the strains studied, isolated from community- and hospital-located kitchen carriers, respectively, were resistant to penicillin and ampicillin, most of the strains were susceptible to the remaining

Table 2. Production of staphylococcal enterotoxins by $S$. aureus isolates obtained from food handlers

\begin{tabular}{|c|c|c|c|c|}
\hline \multirow[b]{2}{*}{ Kitchen } & \multirow{2}{*}{$\begin{array}{l}\text { Food } \\
\text { handler no. }\end{array}$} & \multirow{2}{*}{$\begin{array}{c}\text { Number of enterotoxigenic } \\
\text { strains/number of strains } \\
\text { tested }\end{array}$} & \multicolumn{2}{|c|}{ Enterotoxins produced by isolates from } \\
\hline & & & Nares & Hands \\
\hline \multicolumn{5}{|c|}{ Community } \\
\hline \multirow[t]{4}{*}{ I } & 1 & $4 / 4$ & B & $\mathrm{Nd}$ \\
\hline & 2 & $2 / 7$ & $\mathrm{Nd}$ & $\mathrm{ABE}$ \\
\hline & 3 & $1 / 7$ & $\mathrm{Nd}$ & $\mathrm{AB}$ \\
\hline & 4 & $7 / 10$ & $\mathrm{~B}^{*}$ & $\mathrm{~B}$ \\
\hline \multirow[t]{3}{*}{ II } & 5 & $9 / 9$ & $A B E^{\dagger} ; C^{*}$ & $\mathrm{C}$ \\
\hline & 6 & $2 / 3$ & $\mathrm{Nd}$ & $\mathrm{A} ; \mathrm{CD}$ \\
\hline & 7 & $1 / 4$ & $\mathrm{Nd}$ & A \\
\hline III & 8 & $6 / 6$ & $\mathrm{~B}^{\S}$ & $\mathrm{B}$ \\
\hline IV & 9 & $4 / 5$ & $\mathrm{C}$ & $\mathrm{Nd}$ \\
\hline V & 10 & $3 / 3$ & $\mathrm{C} ; \mathrm{AB}^{\mathrm{Il}}$ & $\mathrm{Nd}$ \\
\hline \multicolumn{5}{|l|}{ Hospital } \\
\hline \multirow[t]{7}{*}{ I } & 11 & $2 / 3$ & $\mathrm{C}$ & $\mathrm{Nd}$ \\
\hline & 12 & $5 / 5$ & $\mathrm{C}$ & $\mathrm{Nd}$ \\
\hline & 13 & $1 / 1$ & A & $\mathrm{Nd}$ \\
\hline & 14 & $1 / 1$ & $\mathrm{~A}$ & $\mathrm{Nd}$ \\
\hline & 15 & $2 / 4$ & $\mathrm{Nd}$ & $\mathrm{A}$ \\
\hline & 16 & $1 / 1$ & $\mathrm{Nd}$ & $\mathrm{AE}$ \\
\hline & 17 & $5 / 5$ & B & $\mathrm{Nd}$ \\
\hline \multirow[t]{6}{*}{ II } & 18 & $2 / 2$ & $\mathrm{C} ; \mathrm{AC}$ & $\mathrm{Nd}$ \\
\hline & 19 & $1 / 1$ & $\mathrm{C}$ & $\mathrm{Nd}$ \\
\hline & 20 & $1 / 2$ & $\mathrm{C}$ & $\mathrm{Nd}$ \\
\hline & 21 & $1 / 3$ & $\mathrm{~A}$ & $\mathrm{Nd}$ \\
\hline & 22 & $1 / 1$ & $\mathrm{Nd}$ & $\mathrm{C}$ \\
\hline & 23 & $4 / 4$ & $\mathrm{C}$ & $\mathrm{Nd}$ \\
\hline III & 24 & $1 / 5$ & $\mathrm{C}$ & $\mathrm{Nd}$ \\
\hline \multirow[t]{2}{*}{ IV } & 25 & $5 / 5$ & $\mathrm{C}$ & $\mathrm{Nd}$ \\
\hline & 26 & $3 / 3$ & $\mathrm{C}$ & $\mathrm{Nd}$ \\
\hline
\end{tabular}

$\mathrm{Nd}$, no enterotoxin-producing strain of $S$. aureus detected.

*Five SEB-producing colonies were obtained from nares and two from hands.

${ }^{\dagger}$ Strain carrying the $m e c A$ gene.

FFive SEC-producing colonies were isolated from nares and three from hands

${ }^{\$}$ Five SEB-producing colonies were isolated from nares and one from hands.

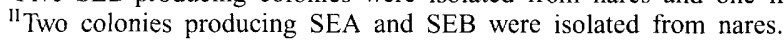


Table 3. Antibiotic susceptibility patterns of $130 \mathrm{~S}$. aureus isolates from food handlers

\begin{tabular}{|c|c|c|c|c|c|c|c|c|c|c|c|c|c|}
\hline \multirow{2}{*}{$\begin{array}{l}\text { Kitchen } \\
\text { type }\end{array}$} & \multirow{2}{*}{$\begin{array}{l}\text { Number of strains } \\
\text { tested }^{*}\end{array}$} & \multicolumn{12}{|c|}{ Number of strains resistant to } \\
\hline & & $\mathrm{PN}$ & $\mathrm{CF}$ & AP & $\mathrm{AM}$ & IMP & $\mathrm{TC}$ & ER & $\mathrm{CL}$ & $\mathrm{VC}$ & $\mathrm{OX}$ & GM & SFT \\
\hline Community & 63 & 51 & 1 & 51 & 1 & 1 & 13 & 5 & 1 & 0 & $1^{\dagger}$ & 1 & 1 \\
\hline Hospital & 67 & 63 & 2 & 63 & 2 & 2 & 17 & 22 & 2 & 0 & $2^{\dagger}$ & 2 & 2 \\
\hline
\end{tabular}

PN, penicillin; CF, cephalothin; AP, ampicillin; AM, amikacin; IMP, imipenem; TC, tetracycline; ER, erythromycin; CL, clindamycin; VC, vancomycin; OX, oxacillin; GM, gentamicin; SFT, sulphamethoxazole-trimethoprim.

${ }^{*}$ In total, 130 strains of $S$. aureus were obtained from 91 food handlers.

${ }^{\dagger}$ Strains identified as MRSA by an agar screen and confirmed with a probe for mecA.

antibiotics tested. However, increased resistance to erythromycin $(21 \%)$ and tetracycline $(23 \%)$ was observed, mainly among hospital-worker isolates. When disk diffusion tests were used, all of the strains studied were oxacillin-susceptible. However, screening on methicillin $25 \mathrm{mg} / \mathrm{L}$ agar detected MRSA isolates from the nares of three carriers. The methicillin-resistant strains were multiresistant and showed susceptibility only to vancomycin. The presence of the $m e c A$ gene in these strains was confirmed with the specific mecA probe (Fig. 1).

\section{PFGE patterns}

Fourteen major PFGE patterns were observed following analysis of 24 enterotoxigenic $S$. aureus isolates (Table 4). All the SEA-producing strains tested had the same PFGE pattern, except for two multiresistant SEA strains. Four SEB-producing strains yielded three different PFGE patterns. Finally, 13 SEC-producing

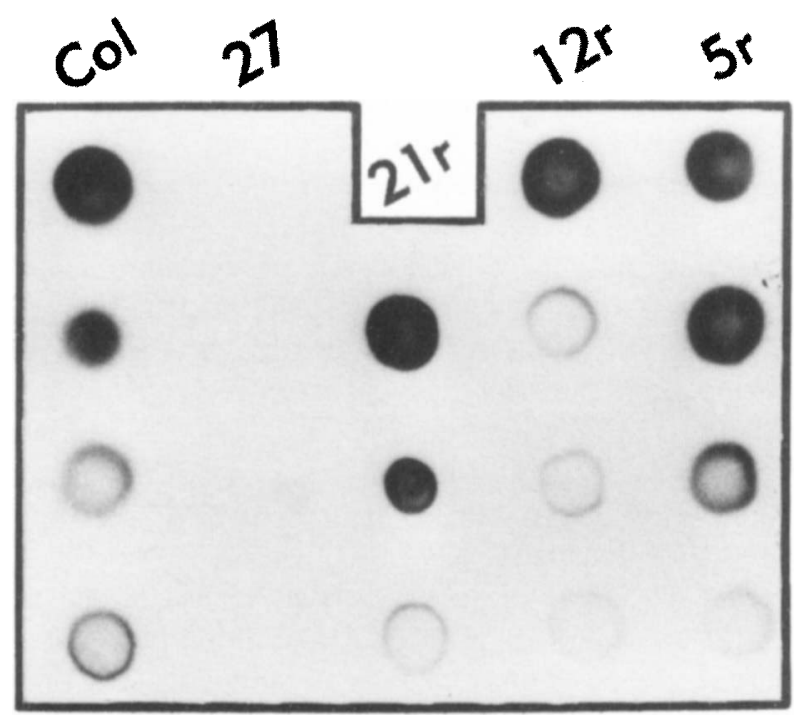

Fig. 1. Dot-blot hybridisation with a $m e c A$-specific probe. Dilutions of DNA preparations of $S$. aureus strains $21 \mathrm{r}$, $12 \mathrm{r}$ and $5 \mathrm{r}$ (strains that grew on methicillin $25 \mathrm{mg} / \mathrm{L}$ screening agar) were hybridised with the $m e c A$ probe as described in Materials and methods. S. aureus strain Col was a known mecA-positive control and strain 27 (susceptible on screening agar) was used as a mecAnegative control. strains yielded eight different PFGE patterns. Two of the three MRSA isolates had a PFGE pattern similar to that of the Brazilian epidemic multiresistant clone III::B:A (Fig. 2a) [23], differing by only one PFGE band (Fig. 2b). In addition to these two MRSA strains, six hospital isolates belonging to clone III::B:A were tested for enterotoxin production. Most of these strains produced different combinations of enterotoxins, although they appeared to be closely related by PFGE typing (Table 5).

\section{Discussion}

It has been reported previously that $10-50 \%$ of the human population are healthy carriers of $S$. aureus $[35,36]$ and that about $30 \%$ of these strains are enterotoxigenic $S$. aureus [9]. However, lower (6.4$16.7 \%)$ and higher $(47-76 \%)$ percentages of enterotoxin-producing $S$. aureus isolates have also been described [9, 37-42]. The study presented in this paper found that $91(46.4 \%)$ of 196 kitchen workers harboured $S$, aureus in their anterior nares, on their hands or at both sites. The total incidence of $S$. aureus was similar between workers from community- and hospital-located kitchens $(43.3 \%$ and $49.5 \%$, respectively). However, as observed previously [35, 43], the frequency of nose isolates was significantly higher ( $\left.<<0.05 ; \chi^{2}\right)$ among hospital workers. The lower recovery of $S$. aureus from the hands of hospital kitchen workers might be related to implementation of hospital control measures to stop transmission of epidemic bacteria. The overall incidence of enterotoxigenic $S$. aureus was $32.6 \%$ and $23.8 \%$ for hospital- and community-located kitchen isolates, respectively. However, this difference was not significant.

The predominance of specific enterotoxin types among $S$. aureus isolates from human carriers is variable. Adesiyun et al. [44] found that SEA was produced by $32.7 \%$ of all enterotoxigenic strains, while SEC and SED were produced by $6.8 \%$ and $6.3 \%$, respectively, of the strains examined. In contrast, Reali [42] found that $S$. aureus strains producing SEB were the most common isolates. The present study found that $50 \%$ of the $S$. aureus isolates produced SEC, 23.1\% SEA and $15.4 \%$ SEB. A predominance of SEC-producing $S$. 
Table 4. Genotypic and phenotypic characterisation of enterotoxigenic and methicillin-resistant isolates of $S$. aureus

\begin{tabular}{|c|c|c|c|c|c|c|c|c|c|c|c|c|c|c|c|c|}
\hline \multirow{2}{*}{\multicolumn{2}{|c|}{$\begin{array}{l}\text { Food } \\
\text { handler } \\
\text { no. }\end{array}$}} & \multirow{2}{*}{$\begin{array}{l}\text { Enterotoxin } \\
\text { types or } \\
\text { combinations }\end{array}$} & \multirow{2}{*}{$\begin{array}{c}\text { PFGE } \\
\text { pattern }\end{array}$} & \multirow[b]{2}{*}{ Kitchens* } & \multicolumn{12}{|c|}{ Disk diffusion test results } \\
\hline & & & & & PN & $\mathrm{CF}$ & AP & $\mathrm{AM}$ & IMP & $\mathrm{TC}$ & ER & $\mathrm{CL}$ & $\mathrm{VC}$ & OX & GM & SFT \\
\hline \multirow[t]{22}{*}{ MSSA } & 1 & $\mathrm{~B}$ & A & CK I & $\mathrm{R}$ & $\mathrm{S}$ & $\mathrm{R}$ & $\mathrm{S}$ & $\mathrm{S}$ & $\mathrm{S}$ & $\mathrm{S}$ & $\mathrm{S}$ & $\mathrm{S}$ & $\mathrm{S}$ & $\mathrm{S}$ & $\mathrm{S}$ \\
\hline & 4 & $\mathrm{~B}$ & Al & CK I & $\mathrm{R}$ & $\mathrm{S}$ & $\mathrm{R}$ & $\mathrm{S}$ & $\mathrm{S}$ & $\mathrm{S}$ & $\mathrm{S}$ & $\mathrm{S}$ & $\mathrm{S}$ & $\mathrm{S}$ & $\mathrm{S}$ & $\mathrm{S}$ \\
\hline & 17 & $\mathrm{~B}$ & $\mathrm{~B}$ & HK I & $\mathrm{R}$ & $\mathrm{S}$ & $\mathrm{R}$ & $\mathrm{S}$ & $\mathrm{S}$ & $\mathrm{R}$ & $\mathrm{R}$ & $\mathrm{S}$ & $\mathrm{S}$ & $\mathrm{S}$ & $\mathrm{S}$ & $\mathrm{S}$ \\
\hline & 8 & $\mathrm{~B}$ & $\mathrm{C}$ & CK III & $\mathrm{R}$ & $\mathrm{S}$ & $\mathrm{R}$ & $\mathrm{S}$ & $\mathrm{S}$ & $\mathrm{S}$ & $\mathrm{S}$ & $\mathrm{S}$ & S & $\mathrm{S}$ & $\mathrm{S}$ & $\mathrm{S}$ \\
\hline & 6 & $\mathrm{~A}$ & $\mathrm{D}$ & CK II & $\mathrm{R}$ & $\mathrm{S}$ & $\mathrm{R}$ & $\mathrm{S}$ & $\mathrm{S}$ & $\mathrm{S}$ & $\mathrm{S}$ & $\mathrm{S}$ & $\mathrm{S}$ & $\mathrm{S}$ & $\mathrm{S}$ & $\mathrm{S}$ \\
\hline & 7 & A & D1 & CK II & $\mathrm{R}$ & $\mathrm{S}$ & $\mathrm{R}$ & $\mathrm{S}$ & $\mathrm{S}$ & $\mathrm{R}$ & $\mathrm{R}$ & $\mathrm{S}$ & $\mathrm{S}$ & $\mathrm{S}$ & $\mathrm{S}$ & $\mathrm{S}$ \\
\hline & 13 & A & D2 & HK I & $\mathrm{R}$ & $\mathrm{S}$ & $\mathrm{R}$ & $\mathrm{S}$ & $\mathrm{S}$ & $\mathrm{R}$ & $\mathrm{R}$ & $\mathrm{S}$ & S & $\mathrm{S}$ & $\mathrm{S}$ & $\mathrm{S}$ \\
\hline & 14 & A & D2 & HK I & $\mathrm{R}$ & $\mathrm{S}$ & $\mathrm{R}$ & $\mathrm{S}$ & S & I & $\mathrm{R}$ & $\mathrm{S}$ & $\mathrm{S}$ & $\mathrm{S}$ & $\mathrm{S}$ & $\mathrm{S}$ \\
\hline & 15 & A & D2 & HK I & $\mathrm{R}$ & $\mathrm{S}$ & $\mathrm{R}$ & $\mathrm{S}$ & $\mathrm{S}$ & $\mathrm{R}$ & $\mathrm{R}$ & $\mathrm{S}$ & $\mathrm{S}$ & $\mathrm{S}$ & $\mathrm{S}$ & $\mathrm{S}$ \\
\hline & 25 & $\mathrm{C}$ & $\mathrm{E}$ & HK IV & $\mathrm{R}$ & $\mathrm{S}$ & $\mathrm{R}$ & $\mathrm{S}$ & $\mathrm{S}$ & $\mathrm{S}$ & $\mathrm{S}$ & $\mathrm{S}$ & $\mathrm{S}$ & $\mathrm{S}$ & $\mathrm{S}$ & $\mathrm{S}$ \\
\hline & 26 & C & $\mathrm{F}$ & HK IV & $\mathrm{S}$ & $\mathrm{S}$ & $\mathrm{S}$ & $\mathrm{S}$ & $\mathrm{S}$ & $\mathrm{S}$ & $\mathrm{S}$ & $\mathrm{S}$ & $\mathrm{S}$ & $\mathrm{S}$ & $\mathrm{S}$ & S \\
\hline & 10 & $\mathrm{C}$ & $\mathrm{F}$ & CK V & $\mathrm{R}$ & $\mathrm{S}$ & $\mathrm{R}$ & $\mathrm{S}$ & $\mathrm{S}$ & $\mathrm{S}$ & $\mathrm{S}$ & $\mathrm{S}$ & $\mathrm{S}$ & $\mathrm{S}$ & $\mathrm{S}$ & $\mathrm{S}$ \\
\hline & 5 & $\mathrm{C}$ & G & CK II & $\mathrm{R}$ & $\mathrm{S}$ & $\mathrm{R}$ & $\mathrm{S}$ & $\mathrm{S}$ & $\mathrm{S}$ & $\mathrm{S}$ & $\mathrm{S}$ & $\mathrm{S}$ & $\mathrm{S}$ & $\mathrm{S}$ & $\mathrm{S}$ \\
\hline & 18 & $\mathrm{C}$ & $\mathrm{H}$ & HK II & $\mathrm{R}$ & $\mathrm{S}$ & $\mathrm{R}$ & $\mathrm{S}$ & $\mathrm{S}$ & $\mathrm{S}$ & $\mathrm{R}$ & $\mathrm{S}$ & $\mathrm{S}$ & $\mathrm{S}$ & $\mathrm{S}$ & $\mathrm{S}$ \\
\hline & 19 & $\mathrm{C}$ & $\mathrm{G}$ & HK II & $\mathrm{R}$ & $\mathrm{S}$ & $\mathrm{R}$ & $\mathrm{S}$ & $\mathrm{S}$ & $\mathrm{R}$ & $\mathrm{S}$ & $\mathrm{S}$ & $\mathrm{S}$ & $\mathrm{S}$ & $\mathrm{S}$ & $\mathrm{S}$ \\
\hline & 20 & $\mathrm{C}$ & I & HK II & $\mathrm{R}$ & $\mathrm{S}$ & $\mathrm{R}$ & $\mathrm{S}$ & $\mathrm{S}$ & $\mathrm{S}$ & $\mathrm{S}$ & $\mathrm{S}$ & $\mathrm{S}$ & $\mathrm{S}$ & $\mathrm{S}$ & $\mathrm{S}$ \\
\hline & 11 & $\mathrm{C}$ & $J$ & HK II & $\mathrm{R}$ & $\mathrm{S}$ & $\mathrm{R}$ & $\mathrm{S}$ & $\mathrm{S}$ & $\mathrm{S}$ & $\mathrm{S}$ & $\mathrm{S}$ & $\mathrm{S}$ & $\mathrm{S}$ & $\mathrm{S}$ & $\mathrm{S}$ \\
\hline & 12 & $\mathrm{C}$ & $\mathrm{Jl}$ & HK I & $\mathrm{R}$ & $\mathrm{S}$ & $\mathrm{R}$ & $\mathrm{S}$ & $\mathrm{S}$ & $\mathrm{S}$ & $\mathrm{S}$ & $\mathrm{S}$ & $\mathrm{S}$ & $\mathrm{S}$ & $\mathrm{S}$ & $\mathrm{S}$ \\
\hline & 22 & $\mathrm{C}$ & I & HK I & $\mathrm{R}$ & $\mathrm{S}$ & $\mathrm{R}$ & $\mathrm{S}$ & $\mathrm{S}$ & $\mathrm{S}$ & $\mathrm{S}$ & $\mathrm{S}$ & $\mathrm{S}$ & $\mathrm{S}$ & $\mathrm{S}$ & $\mathrm{S}$ \\
\hline & 23 & $\mathrm{C}$ & $\mathrm{K}$ & HK II & $\mathrm{R}$ & $\mathrm{S}$ & $\mathrm{R}$ & $\mathrm{S}$ & $\mathrm{S}$ & $\mathrm{R}$ & $\mathrm{S}$ & $\mathrm{S}$ & $\mathrm{S}$ & $\mathrm{S}$ & $\mathrm{S}$ & $\mathrm{S}$ \\
\hline & 24 & $\mathrm{C}$ & $\mathrm{Kl}$ & HK III & $\mathrm{R}$ & $\mathrm{S}$ & $\mathrm{R}$ & $\mathrm{S}$ & $\mathrm{S}$ & $\mathrm{S}$ & $\mathrm{S}$ & $\mathrm{S}$ & $\mathrm{S}$ & $\mathrm{S}$ & $\mathrm{S}$ & $\mathrm{S}$ \\
\hline & 9 & $\mathrm{C}$ & $\mathrm{L}$ & CK IV & $\mathrm{R}$ & $\mathrm{S}$ & $\mathrm{R}$ & $\mathrm{S}$ & $\mathrm{S}$ & $\mathrm{S}$ & $\mathrm{S}$ & $\mathrm{S}$ & $\mathrm{S}$ & $\mathrm{S}$ & $\mathrm{S}$ & $\mathrm{S}$ \\
\hline \multirow{3}{*}{ MRSA } & $5 \mathrm{r}$ & $\mathrm{ABE}$ & M & CK II & $\mathrm{R}$ & $R$ & $\mathrm{R}$ & $\mathrm{R}$ & $\mathrm{R}$ & $\mathrm{R}$ & $\mathrm{R}$ & $\mathrm{R}$ & $\mathrm{S}$ & $\mathrm{R}$ & $\mathrm{R}$ & $\mathrm{R}$ \\
\hline & $12 r$ & $\mathrm{Nd}$ & $\mathrm{N}$ & HK I & $\mathrm{R}$ & $\mathrm{R}$ & $\mathrm{R}$ & $\mathrm{R}$ & $\mathrm{R}$ & $\mathrm{R}$ & $\mathrm{R}$ & $\mathrm{R}$ & $\mathrm{S}$ & $\mathrm{R}$ & $\mathrm{R}$ & $\mathrm{R}$ \\
\hline & $21 \mathrm{r}$ & A & $\mathrm{N}$ & HK II & $\mathrm{R}$ & $\mathrm{R}$ & $\mathrm{R}$ & $\mathrm{R}$ & $\mathrm{R}$ & $\mathrm{R}$ & $\mathrm{R}$ & $\mathrm{R}$ & $\mathrm{S}$ & $\mathrm{R}$ & $\mathrm{R}$ & $\mathrm{R}$ \\
\hline
\end{tabular}

PN, penicillin; CF, cephalothin; AP, ampicillin: AM, amikacin; IMP, imipenem; TC, tetracycline; ER, erythromycin; CL, clindamycin; VC, vancomycin; OX, oxacillin; GM, gentamicin; SFT, sulphamethoxazole + trimethoprim; R, resistant; S, sensitive; Nd; no enterotoxin production detected.

${ }^{*} \mathrm{CKI}-\mathrm{V}$, community-located kitchens; HKI-IV, hospital-located kitchens.

aureus strains among food handlers has been observed previously [37, 40, 41,45]. In Brazil, few food-borne intoxication outbreaks caused by enterotoxigenic $S$. aureus have been reported. In these studies the most frequent enterotoxin types produced were SEA, or SEA and SEB [46-48]. However, Bergdoll et al. $[49,50]$ found that SEC was involved in four different food-poisoning outbreaks in Curitiba City, Brazil. The present study observed production of two or more enterotoxin types by isolates from three workers. Coproduction of different toxin types might be important in increasing the toxigenic effect of these superantigens. Some studies have suggested that the production of enterotoxins by $S$. aureus isolates may also be important in the pathogenesis of infections other than staphylococcal food poisoning [38, 51, 52]. However, the possible involvement of these toxins in other staphylococcal diseases is not well documented.

Of the $130 \mathrm{~S}$. aureus strains analysed, $81-94 \%$ were resistant to penicillin $G$ and ampicillin. Increased resistance $(33 \%)$ to erythromycin was found in hospital isolates compared with community isolates $(8 \%)$. This increase might be related to the frequent use of this drug in hospitals. About $3 \%$ of the strains carried the mecA gene, and two of three MRSA isolates had a PFGE pattern very similar to that of the Brazilian epidemic MRSA clone, designated previously as clone III::B:A [23] and assigned PFGE pattern $\mathrm{N}$ in this study (Table 4). This clone has caused hospital outbreaks in six different Brazilian cites $[23,53]$, ranging from Manaus in the north to Porto Alegre in the south $(5300 \mathrm{~km}$ from Manaus), and the results show that a subclone of this epidemic MRSA clone is also colonising a hospital in Teresina.

A food-related hospital outbreak of infection caused by MRSA has been described previously [22] and, combined with the results from the present study, these data indicate that kitchen workers may contribute to hospital dissemination of epidemic multiresistant $S$. aureus clones. Hospital kitchen workers carrying MRSA seem not to be rare and should be given special attention during control measures to stop MRSA transmission during outbreaks. A further MRSA clone was isolated from a carrier in a community-located kitchen. Clone III::B:A and other MRSA clones have also been observed among $S$. aureus isolates from healthy carriers in Rio de Janeiro [54]. The wide dissemination of these multiresistant $S$. aureus clones in the community would be a serious health problem and health counsellors should not underestimate this risk.

PFGE analysis of the enterotoxigenic strains revealed clonal diversity, with the exception of the five SEAproducing strains that belonged to the same clone. Similar diversity was reported previously among SECproducing $S$. aureus isolates from human and food 

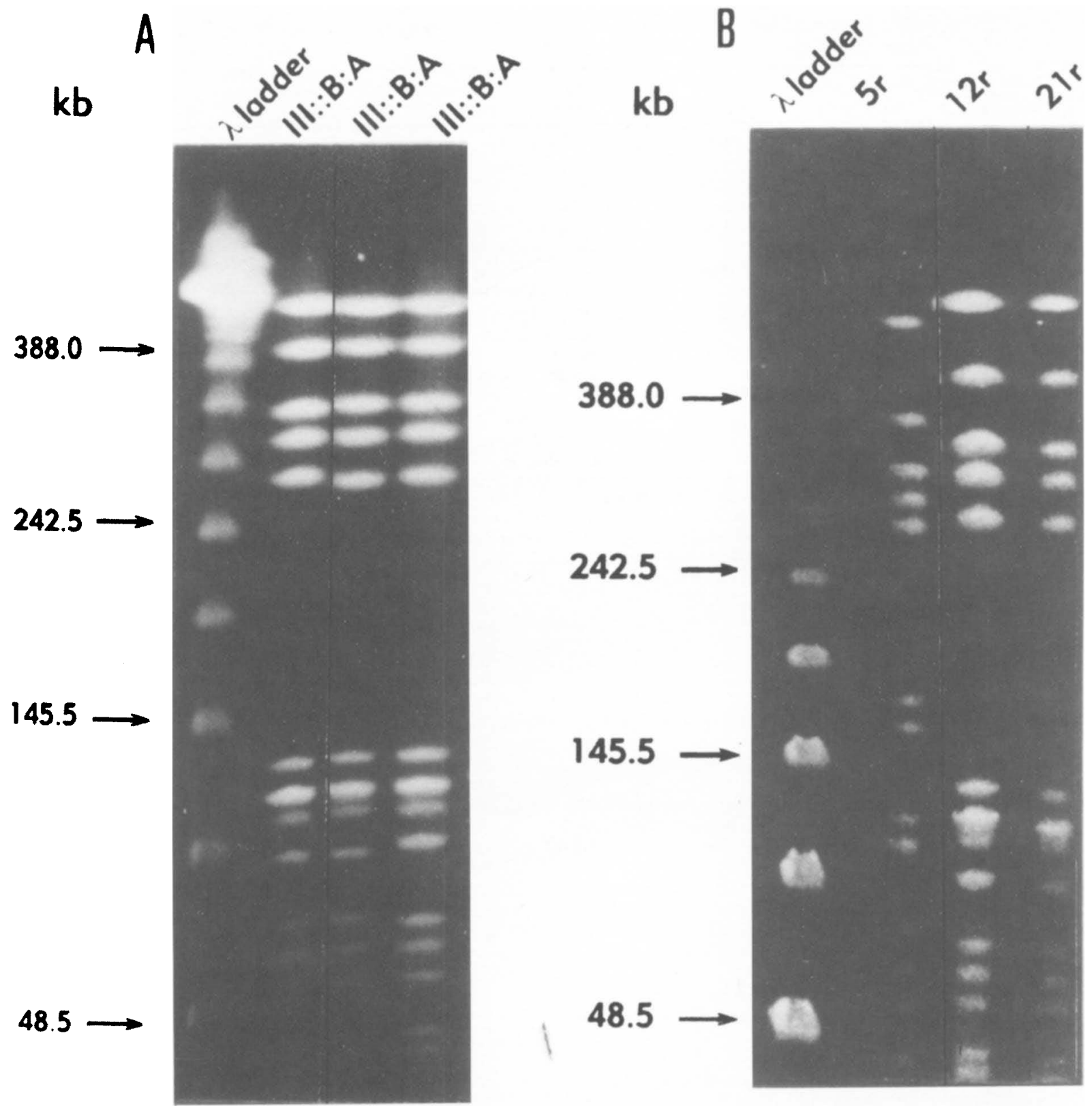

Fig. 2. Examples of SmaI PFGE patterns. A, strains representative of Brazilian Epidemic Clone III::B:A. B, strains isolated from hospital food handlers, showing that strains $12 \mathrm{r}$ and $21 \mathrm{r}$ had essentially the same SmaI PFGE pattern as the representatives of clonal type III::B:A, while strain $5 \mathrm{r}$ belonged to a different SmaI PFGE type.

sources [55]. In contrast, Renaud et al. [19] found that 39 SEB-producing strains probably originated from only three clones.

Eight isolates belonging to MRSA clone III::B:A varied from non-enterotoxin producers to producers of different combinations of enterotoxin types (Table 5). Thus, acquisition of ent genes by this clone seems to have occurred after the acquisition of mecA and the Tn554 transposon. The diversity of enterotoxin types produced by this clone suggests that the acquisition of ent genes might have occurred by horizontal transmission. Marr et al. [55] studied 15 SEC-producing strains and confirmed the wide spread transmission of this gene among $S$. aureus isolates.
In conclusion, these results suggest that the recent acquisition of ent genes by isolates belonging to MRSA clone III::B:A occurred by horizontal transfer and that this phenomenon might be a common mechanism for spread of ent genes among strains of $S$. aureus. Attention should be given to the dissemination of MRSA clone III::B:A and to the presence of MRSA clones colonising the nares of carriers in hospital- or community-located kitchens.

This work was partially supported by grants from Conselho Nacional de Desenvolvimento Científico e Tecnológico (CNPq), Fundação Coordenação de Pessoal de Nivel Superior (CAPES) and Financiadora de Estudos e Projetos (FINEP). 
Table 5. Production of enterotoxins by isolates belonging to a single MRSA clone

\begin{tabular}{|c|c|c|c|}
\hline $\begin{array}{l}\text { S. aureus } \\
\text { isolate }\end{array}$ & Genotype ${ }^{*}$ & Description & $\begin{array}{l}\text { Enterotoxin } \\
\text { types }^{\dagger}\end{array}$ \\
\hline BMB4792 & III::B:A & $\begin{array}{l}\text { Hospital isolate from } \\
\text { invasive infection }\end{array}$ & SEC \\
\hline BMB5292 & III::B:A & $\begin{array}{l}\text { Hospital isolate from } \\
\text { invasive infection }\end{array}$ & $\mathrm{Nd}$ \\
\hline BMB5592 & III::B:A & $\begin{array}{l}\text { Hospital isolate from } \\
\text { invasive infection }\end{array}$ & $\begin{array}{l}\text { SEA, SEB, } \\
\text { SEC }\end{array}$ \\
\hline BMB6492 & $111:: B: A$ & $\begin{array}{l}\text { Hospital isolate from } \\
\text { invasive infection }\end{array}$ & SEA \\
\hline BMB6792 & III::B:A & $\begin{array}{l}\text { Hospital isolate from } \\
\text { invasive infection }\end{array}$ & SEA, SEC \\
\hline BMB7192 & $111:: B: A$ & $\begin{array}{l}\text { Hospital isolate from } \\
\text { invasive infection }\end{array}$ & $\begin{array}{l}\text { SEA, SEB, } \\
\text { SEC }\end{array}$ \\
\hline $12 \mathrm{r}$ & $\operatorname{PFGE}(\mathrm{N})^{\dagger}$ & $\begin{array}{l}\text { Hospital isolate from } \\
\text { food handler }\end{array}$ & $\mathrm{Nd}$ \\
\hline $21 \mathrm{r}$ & $\operatorname{PFGE}(\mathrm{N})^{*}$ & $\begin{array}{l}\text { Hospital isolate from } \\
\text { food handler }\end{array}$ & SEA \\
\hline
\end{tabular}

$\mathrm{Nd}$, no production of enterotoxin detected.

* Characterisation of $\mathrm{BMB}$ isolates listed has been described previously [23]

${ }^{\dagger}$ Determined by the optimum sensitivity plate (OSP) method [26].

${ }^{\ddagger}$ Strain with a SmaI PFGE pattern essentially identical to strains belonging to clone III::B:A (see

Fig. 2).

\section{References}

1. Baird-Parker AC. The staphylococci: an introduction. Soc Appl Bacteriol Symp Ser 1990; 19: 1S-8S

2. Musher DM, McKenzie SO. Infection due to Staphylococcus aureus. Medicine 1977; 56: 383-409.

3. Cohen ML. Staphylococcus aureus: biology, mechanisms of virulence, epidemiology. J Pediatr 1986; 108: 796-799.

4. Casman EP. Further serological studies of staphylococcal enterotoxin. $J$ Bacteriol 1960; 79: 849-856.

5. Bergdoll MS, Sugiyama H, Dack GM. Staphylococcal enterotoxin. I. Purification. Arch Biochem 1959; 85: 62-69.

6. Borja CR, Bergdoll MS. Purification and partial characterization of enterotoxin C produced by Staphylococcus aureus strain 137. Biochemistry 1967; 6: 1467-1473.

7. Avena RM, Bergdoll MS. Purification and some physicochemical properties of enterotoxin C, Staphylococcus aureus strain 361. Biochemistry 1967; 6: 1474-1480.

8. Reiser RF, Robbins RN, Noleto AL, Khoe GP, Bergdoll MS Identification, purification and some physicochemical properties of staphylococcal enterotoxin C3. Infect Immun 1984; 45: $625-630$.

9. Casman EP, Bennett RW, Dorsey AE, Issa JA. Identification of a fourth staphylococcal enterotoxin, enterotoxin D. J Bacteriol 1967: 94: 1875-1882.

10. Bergdoll MS, Borja CR, Robbins RN, Weiss KF. Identification of enterotoxin E. Infect Immun 1971; 4: 593-595.

11. Su Y-C, Wong ACL. Identification and purification of a new staphylococcal enterotoxin, H. Appl Environ Microbiol 1995; 61: $1438-1443$.

12. Janeway CA, Yagi J. Conrad PJ et al. T-cell responses to M1s and bacterial proteins that mimic its behaviour. Immunol Rev 1989; 107: $61-88$.

13. Fraser, JD. High-affinity binding of staphylococcal enterotoxins $\mathrm{A}$ and $\mathrm{B}$ to HLA-DR Nature 1989; 339: $221-223$.

14. Betley MJ, Mekalanos JJ. Staphylococcal enterotoxin A is encoded by phage. Science 1985; 229: 185-187.

15. Johns MB, Khan SA. Staphylococcal enterotoxin B gene is associated with a discrete genetic element. J Bacteriol 1988; 170: 4033-4039.

16. Betley MJ, Borst DW, Regassa LB. Staphylococcal enterotoxins, toxic shock syndrome toxin and streptococcal pyrogenic exotoxins: a comparative study of their molecular biology. Chem Immunol 1992; 55: 1-35.

17. Bayles KW, Iandolo JJ. Genetic and molecular analysis of the gene encoding staphylococcal enterotoxin D. J Bacteriol 1989; 171: $4799-4806$.

18. Couch JL, Soltis MT, Betley MJ. Cloning and nucleotide sequence of the type $E$ staphylococcal enterotoxin gene.
$J$ Bacteriol 1988; 170: 2954-2960.

19. Renaud F, Bornstein N, Meugnier H, Forey F, Bes M, Fleurette J. Clonal study of enterotoxin-B producing strains of Staphylococcus aureus. Epidemiol Infect 1994; 112: 501-516.

20. Maple PAC, Hamilton-Miller JMT, Brumfitt W. World-wide antibiotic resistance in methicillin-resistant Staphylococcus aureus. Lancet 1989; 1: 537-540.

21. Voss A, Milatovic D, Wallrauch-Schwarz C, Rosdahl VT, Braveny I. Methicillin-resistant Staphylococcus aureus in Europe. Eur J Clin Microbiol Infect Dis 1994; 13: 50-55.

22. Klutymans J, van Leeuwen W, Goessens W et al. Food-initiated outbreak of methicillin-resistant Staphylococcus aureus analyzed by pheno- and genotyping. J Clin Microbiol 1995; 33: $1121-1128$.

23. Teixeria LA, Resenade CA, Ormonde LR et al. Geographic spread of epidemic multiresistant Staphylococcus aureus clone in Brazil. J Clin Microbiol 1995; 33: 2400-2404.

24. International Commission on Microbiological Specifications for Foods (ICMSF). Microorganisms in foods 1: their significance and methods of enumeration, 2 nd edn. Toronto, University of Toronto Press, 1976; 218, 256.

25. Hallander HO. Production of large quantitites of enterotoxin B and other staphylococcal toxin on solid media. Acta Path Microbiol Scand 1965; 63: 299-305.

26. Jarvis AW, Lawrence RC. Production of high titers of enterotoxins for the routine testing of staphylococci. Appl Microbiol 1970; 19: 698-699.

27. Robbins R, Gould S, Bergdoll MS. Detecting the enterogenicity of Staphylococcus aureus strains. Appl Microbiol 1974; 28: $946-950$.

28. Sambrook J, Fritsch EF, Maniatis T. Molecular cloning. A laboratory manual, 2nd edn. Cold Spring Harbor, New York, Cold Spring Harbor Laboratory Press. 1989.

29. de Lencastre H, Couto I, Santos I, Melo-Cristino J, TorresPereira A, Tomasz A. Methicillin-resistant Staphylococcus aureus in a Portuguese hospital: characterization of clone types by a combination of DNA typing methods. Eur $J$ Clin Microbiol Infect Dis 1994; 13: 64-73.

30. Struelens MJ, Deplano A, Godard C, Maes N, Serruys E. Epidemiologic typing and delineation of genetic relatedness of methicillin-resistant Staphylococcus aureus by macrorestriction analysis of genomic DNA by using pulsed-field gel electrophoresis. J Clin Microbiol 1992; 30: 2599-2605.

31. Tenover FC, Arbeit RD, Goering RV et al. Interpreting chromosomal DNA restriction patterns produced by pulsedfield gel electrophoresis: criteria for bacterial strain typing. $J$ Clin Microbiol 1995; 33: 2233-2239.

32. National Committee for Clinical Laboratory Standards. Performance standards for antimicrobial disk susceptibility tests. 
M2-A5, 5th edn., V. 13 No. 24. Villanova, PA, National Committee for Clinical Laboratory Standards. 1993.

33. de Lencastre HSE, Figueiredo AM, Urban C, Rahal J, Tomasz A. Multiple mechanisms of methicillin resistance and improved methods for detection in clinical isolates of Staphylococcus aureus. Antimicrob Agents Chemother 1991; 35: 632-639.

34. Matthews PR, Reed KC, Stewart PR. The cloning of chromosomal DNA associated with methicillin and other resistances in Staphylococcus aureus. J Gen Microbiol 1987; 133: $1919-1929$.

35. Williams REO. Healthy carriage of Staphylococcus aureus: its prevalence and importance. Bacteriol Rev 1963; 27; 56-71.

36. Noble WC, Valkenburg HA, Wolters CHL. Carriage of Staphylococcus aureus in random samples of a normal population. $J$ Hvg 1967; 65: 567-573.

37. Castro MMMV, laria ST. Staphylococcus aureus enterotoxigênico no vestíbulo nasal de manipuladores de alimentos em cozinhas de hospitais do município de João Pessoa PB. [Enterotoxigenic Staphylococcus aureus in the nasal vestibule of food handlers in hospital kitchens of the municipiality of João Pessoa, Paraiba.] Rev Saude Publica 1984; 18: 235-245.

38. Humphreys H. Keane CT, Hone R et al. Enterotoxin production by Staphylococcus aureus isolates from cases of septicaemia and from healthy carriers. J Med Microbiol 1989 28: $163-172$.

39. Nolcto ALS, da Costa Cesar E, Bergdoll MS. Antibodies to staphylococcal enterotoxins and toxic shock syndrome toxin 1 in sera of patients and healthy people in Rio de Janeiro, Brazil. J Clin Microbiol 1986; 24: 809-811.

40. Iaria ST, Furlanetto SMP, Cerqueira-Campos ML. Pesquisa de Staphylococcus aureus enterotoxigênico nas fossas nasais de manipuladores de alimentois em hospitais [Research of enterotoxigenic Staphylococcus aureus in the nasal fossa of hospital food handlers in Sao Paulo, 1976.] Rev Saude Publica 1980; 14: $93-100$

41. Melconian AK, Brun Y, Fleurette J. Enterotoxin production, phage typing and serotyping of Staphylococcus aureus strains isolated from clinical materials and food. J Hyg 1983; 91: $235-242$.

42. Reali D. Enterotoxin A and B production in strains of Staphylococcus aureus isolated from human beings and foods. J Hyg 1982; 88: 103-106.

43. Ballou WR, Cross AS, Williams DY, Keiser J. Zierdt $\mathrm{CH}$ Colonization of newly arrived house staff by virulent staphylococcal phage types endemic to a hospital environment. J Clin Microbiol 1986; 23: 1030-1033.
44. Adesyiun AA, Raji I, Yobe V. Enterotoxigenicity of Staphylococcus aureus from anterior nares of dining hall workers. J Food Protect 1986; 49: 955-957.

45. Adesiyun AA, Prabhakar P, Ali C, Lewis M. Characteristics of Staphylococcus aureus isolated from clinical and non-clinical human sources in Trinidad: susceptibility to bacteriophages and antimicrobial agents, and toxigenicity. Zentralbl Bakteriol 1995; 282: 519-532.

46. Carmo LS, Bergdoll MS. Staphylococcal food poisoning in Belo Horizonte (Brazil). Rev Microbiol 1990; 21: 320-323.

47. Noleto ALS, Tibana A. Outbreak of staphylococcal enterotoxin B food poisoning. Rev Microbiol 1987; 18: 144-145.

48. Pereira ML, do Carmo LS, dos Santos EJ, Bergdoll MS Staphylococcal food. poisoning from cream-filled cake in a metropolitan area of south-eastern Brazil. Rev Suade Publica 1994; 28: $406-409$.

49. Bergdoll MS, Carmo LS, Sikorski Moscalewski W, Oliveira Branco Filho M. Staphylococcal food poisoning in Brazil. Proceedings of the 3rd World Congress on Foodborne Infections and Intoxications, Berlin. 1992. V1: 320-323.

50. Pereira ML, Carmo LS, Lara MA, Dias RS, Bergdoll MS Enterotoxigenic staphylococci from food handlers working in an industrial kitchen in Belo Horizonte, MG (Brazil). Rev Microbiol 1994; 25: 161-165.

51. Crass BA, Bergdoll MS. Involvement of staphylococcal enterotoxins in nonmenstrual toxic shock syndrome. $J$ Clin Microbiol 1986; 23: 1138-1139.

52. Lehn N, Schaller E, Wagner H, Kronke M. Frequency of toxic shock syndrome toxin- and enterotoxin-producing clinical isolates of Staphvlococcus aureus. Eur J Clin Microbiol Infect Dis 1995; 14: 43-46.

53. Santos Filho L, Sader HS, Bortolotto VI, Gontijo Filho PP, Pignatari AC. Analysis of the clonal diversity of Staphylococcus aureus methicillin-resistant strains isolated at João Pessoa, State of Paraiba, Brazil. Mem Inst Oswaldo Cruz 1996; 91: $101-105$.

54. Falcão MHL, Borges-Neto AA, Fracalanzza SEL, Seldin L, Figueiredo AMS. Associations of methicillin-resistant and susceptible strains of Staphylococcus aureus isolated from the same colonization site from healthy humans in Rio de Janeiro. Program and Ahstracts of The 94th General Meeting of the American Society for Microbiology, 1994: 563.

55. Marr JC, Lyon JD, Roberson JR, Lupher M, Davis WC, Bohach GA. Characterization of novel type C staphylococcal enterotoxins: biological and evolutionary implications. Infect Immun 1993; 61: 4254-4262. 